\title{
4. Questioning public interest journalism in New Caledonia
}

\section{COMMINIARY}

François Hollande's five-year term of office as President of France overlaps a critical time for the future of New Caledonia, where a referendum is set to take place between 2014 and 2019 to decide whether or not the archipelago will remain within the French Republic or become independent. New Caledonia has a unique status in the polity of France. It is a special collectivity, more than a colonial territory, but less than a fully-independent state within a Francophone commonwealth. It is the author's contention, however, that within the public sphere of this unique political entity, it is the media in New Caledonia, rather than the government of metropolitan France, that will play the decisive role in influencing the future of New Caledonia. Therefore, this commentary sets out to interrogate the role local media could play in the future of the archipelago and the implications for the New Caledonian public.

Keywords: custom, Francophone, indigenous media, Kanak media, New Caledonia, public-interest journalism, liquid modernity

\section{MARIE M'BALA-NDI}

James Cook University

I N 1985, two French anthropologists, Pierre Bourdieu and Alban Bensa, discussed the image of the Kanak people as it is framed within a French traditional anthropological framework, largely constructed around the work of Maurice Leenhardt (1878-1954), a French pastor who conducted extensive research on the indigenous population of New Caledonia.

During their conversation Bourdieu and Bensa tackled various themes such as the representation of Kanaks within the French colonial ethnological tradition, the abuses of colonialism toward this population, the Kanaks' anti-colonial protests. They also noted how a too simplistic modernity/tradition dichotomy can be avoided when analysing New Caledonian society, by 
deploying an ethnographic approach more respectful of facts and reality. Bensa (1985) said:

The ethnological approach provides a good alternative to a tradition/ modernity dichotomy within which a technocratic geography, among other things, likes to lock itself, building sociological divides based on numbers that prove the Kanaks' existence in global economy and arguing that if they leave the tribe they would have to choose between ancestral customs and modern life. This simplistic reasoning incites a moralist discourse [...] As missionaries claimed that Kanaks had to abandon life in their tribe to be ready to receive Christ, now it is claimed that Kanaks need to leave the tribe to gain access to modernity. (Bensa, 1985, p. 80)

It is very significant that, during this discussion, Bensa also mentioned journalism arguing: '[...] This opposition between custom and modernity also haunts today's journalism (p. 80).'

Nearly 30 years later, not much has changed in New Caledonia where it can be argued that two distinct media spheres - one reflecting many aspects of the normative functions and principles of Western journalism and another mirroring the features of a more indigenous way of communicating and exchanging information - can be discerned. In an interview conducted in August 2011 for a wider study examining journalism practice in New Caledonia, a journalist from the main daily newspaper Les Nouvelles Calédoniennes said: 'Currently, journalism in New Caledonia reinforces the image of two distinct blocks, of a divide between Kanaks and Europeans (personal communication,' (August 2011). ${ }^{1}$

As argued by Maclellan \& Chesneaux (1998), in New Caledonia: [...] 'antagonism between white colonisers and colonised blacks remains deeprooted, despite the formal equality of citizenship established by the constitution of the Fifth Republic' (p. 147).

Beyond the notion of antagonism, this commentary argues that a real 'divide' exists between Kanaks and white settlers in New Caledonia not only when looking at the archipelago's political and socio-cultural environment, but also while examining New Caledonia's media sphere-and, to another extent, journalism practices among Kanak and metropolitan journalists. 


\section{Disregarded protest}

While pro-independence protests of the Kanaks against the French settlers and, more broadly, the French Republic, have been extensively documented in the global media and academic literature, there is another dispute taking place in New Caledonia. It is a quiet and diffused quarrel, but it is still a protest-against Western impositions and dominance (for Kanak journalists and their leaders), and against customs or indigenous rules shaping communication and information exchanges with local communities (for metropolitan journalists).

As Chanter (1999) argued, 'The metropolitan journalists' presence in the territory, working on the daily newspaper, was a product of colonialism enabled by the imposition of French political, economic and cultural practices on the indigenous inhabitants and the emergence of new institutions, among them a French language press' (p. 192). However, in the mid to late 1980s, pro-independence movements in New Caledonia have also given rise to the establishment of indigenous pro-independence outlets. Maclellan (2009) wrote:

New Caledonia's independence movement needed outlets to carry its message to supporters in the indigenous Kanak population. To challenge the dominance of conservative voices in the media, the FLNKS helped establish the community station Radio Djiido in 1985. Together with the magazine Bwenando, Djiido was the only outlet to provide alternative views to the anti-independence voices which dominated the airwaves. (Maclellan, 2009, p. 206)

Local media in New Caledonia have a tendency to show antagonism towards the discourses of opposing political forces in periods of important political transitions. For example, Chanter (1999) argued 'prior to the election of socialist President François Mitterrand in 1981, the territory's state radio and television services manifested a [...] resolute opposition to independence, achieved largely through the denial of access to Kanak or European proindependence politicians'(p.100).

Discursive exclusions of opposition leaders can also be noted in the practices of pro-independence media. The inconspicuous coverage of the 2009 visit of former French President, Nicolas Sarkozy, by pro-independence news outlets such as Djiido can also illustrate this. During an informal conversation, a Kanak journalist said: 'The country is once again fooled by beautiful speeches and promises of the French Republic' (personal communication, 2009). 
Another journalist from Radio Djiido admitted:

We try our best not to discriminate against anyone as our editorial policy sets it. But we often feel like our own culture catches up with us, and sometimes we feel uneasy about the way white people are behaving. If we are working on a political story involving pro-independence groups and loyalists for example, we do not only give priority to the pro-independence activists because of the station's orientation, but also because of a cultural divide that exists between us [Kanak journalists] and white people. White politicians we interview are sometimes somewhat quarrelsome and they use these big words and have this 'French' eloquence, a concoction that puts us off quickly, and intimidates us just because humility and shyness are important features of our culture and they also impact on our ways of communicating with each other. So, sometimes, depending on the journalist, some journalists might make the choice to give priority to Kanak leaders. (Personal communication, August 2011)

Many of the Kanak journalists interviewed in August 2011 shared this feeling, despite the fact that most of these journalists understand the need to put an end to such practices while reporting on stories involving the opposition. A senior journalist from Radio Djiido said, 'Broadcasting our opponents' message and attempting to encourage discussion is crucial (Personal communication, August 2009).

Antagonism can also be directed towards media practitioners themselves for the sake of this European/Kanak divide. For example, members of the public —often Kanak leaders - can, sometimes, sideline metropolitan journalists in New Caledonia claiming that some information cannot be shared with them because of various secrecy rules of a clan or because of confidentiality clauses framed in an Indigenous system.

A journalist from Les Nouvelles Calédoniennes said:

Metropolitan journalists sometimes find themselves at the mercy of custom leaders as, at times, the only way we can get a story is by observing 'la coutume' (custom protocols). This enables them to dictate not only what we can witness but also, to a more concerning extent, what we can cover, what we can photograph, what words we can report. If we don't play by the rules, we know we will never get any information from these people again. (Personal communication, August 2011) 
It must be noted that structural issues in media ownership also affect the patterns of bias among journalists. The fear of increased editorial pressure among journalists from Les Nouvelles (who recently expressed their concerns in an all-out strike) with the imminent sale of the newspaper by the Hersant Group to local businessmen well illustrates this (Small, 6 April 2013). Moreover, political disputes in New Caledonia and the state of press freedom in France also have a significant impact on journalism practice in the archipelago.

As Perrottet \& Robie (2011) observe:

[...] There are pressures on press freedom, from local political disputes and also changes to media laws that affect France's three Pacific dependencies. Private radio stations $[\ldots]$ receive grants from the three provincial administrations in New Caledonia, which opens the way for political pressure to be applied. (Perrottet \& Robie, 2011, p. 175)

Nevertheless, this commentary rather focuses on reforms in the broadcast sector and journalistic practice among journalists from Les Nouvelles and Djiido to suggest that the current media landscape of New Caledonia is a mere reflection of the socio-cultural and political context of the archipelago: that is polarised. This polarisation represents a significant threat to fair, transparent and responsible journalism in New Caledonia.

As Meadows (2005) argued in a discussion about the indigenous public sphere:

Many indigenous people have responded by turning their back on mainstream media and engaging in their own forms of cultural production. It is a global phenomenon, which occurs in a diverse range of sites appropriating community-based-media $[\ldots]$ and creating $[\ldots]$ 'indigenous public spheres. (Meadows, 2005, p. 37)

The New Caledonian media landscape is a good illustration of this phenomenon, with the emergence in the late 1980s of indigenous - or Kanakpro-independence news outlets created to 'provide alternative views to the anti-independence voices which dominated the airwaves' (Maclellan 2009, p. 206).

Whereas this commentary focuses on mainstream media in New Caledonia, is must be noted that today, as argued by Maclellan (2009), a number 
of 'local productions like the weekly political review Les Infos, the satirical Chien Bleu or Environnement Nouvelle-Calédonie [...] The long-running cultural magazine Mwa Vee [...] glossies such as Palabre Coutumier [...] the women's magazine Pala Hin Hnemo to VKP Infos' (p. 207) are also changing the media landscape of the archipelago and also provide a space for critical voices from outside the mainstream media.

Currently, significant changes in New Caledonia are taking place in television broadcasting:

Recognition that an act of self-determination between 2014 and 2018 may result in the creation of the newly independent nation of Kanaky has brought forth new proposals for publicly-subsidised television services in New Caledonia. (M'Balla-Ndi \& Harrison, 2012, p.18)

Two separate local television projects were submitted in 2011 to the Conseil Supérieur de l'Audiovisuel (CSA), France's Paris-based national broadcasting regulator, by New Caledonian politicians, Paul Neaoutyine, a Kanak political leader, and proponent of independence, and the former President of New Caledonia (2001-2004), Pierre Frogier:

The supporters of these two projects which aim to be publicly-funded, ${ }^{2}$ NCTV, 'a citizen television' and NC9, 'a consensual television' (Deux nouvelles chaines locales?, 2011), both argue that these channels will complete the audio-visual landscape of New Caledonia by remedying the lack of local content produced by the only 'local' ${ }^{3}$ public television channel, Nouvelle-Calédonie 1ère. (M'Balla-Ndi \& Harrison, 2012, p.19)

Many concerns have been raised regarding these two pending television channels, such as the use of these channels for political propaganda and in February 2012 the CSA announced that only a single project could be funded, recommending a fusion of the two projects. In January 2013, however, the CSA approved the applications of both television stations, which has generated strong public responses especially from the political party Caledonia Together against the NC9 project.

NC9 plans to bring together journalists from two concurrent newsrooms: Radio Djiido and Radio Rythme Bleu. This project might sound innovative and some could see it as a step toward the so-called 'shared destiny'.

However, in February 2011, Gomes highlighted the fact that NC9 plans

78 PACIFIC JOURNALISM REVIEW 19 (1) 2013 
to have an evening news bulletin that will be divided in two parts: 'half an hour will be given to RRB and the other one to Radio Djiido' (Gomes, 2012). A local journalist commented by saying about this development:

I cannot wait to see this. In one bulletin we will be told that a building collapsed somewhere in the city and in the other one we will be told that a revolution is on and that Kanaks have already attacked some buildings of the Republic. (Personal communication, August 2011)

This last statement contains the core of this commentary's argument, which is concerned with the obvious lack of opportunities in the current polarised Caledonian media sphere for a journalism targeting positive social development, and not compromising the public interest.

\section{Public interest journalism in stand-by}

Martin Moore (2007) argued:

Public interest journalism has two elements. The first is as a watchdog, holding the powerful to account, exposing fraud, deceit, corruption, mismanagement and incompetence. [...] The second element of public interest journalism $[\ldots]$ is the responsibility to inform, explain and analyse. Public interest journalists find, digest and distil information that helps the public form views and make decisions. (Moore, 2007, p.33)

The major task of public interest journalism then aims to empower the people and give them all the tools necessary to monitor public life and make well-informed decisions; not by only providing media coverage of specific events or aspects of some events relevant to one specific public sphere but by giving them all sides of a story, all elements of a discourse or all dimensions of an issue, which is a fundamental principle of journalism.

Discussing the threats faced by public interest journalism, Moore (2007) says that although 'public interest journalism is not under direct threat from the public [...] indirectly, it certainly is' (p. 38).

Metropolitan journalists from Les Nouvelles interviewed in 2011 suggest that their audience is mainly metropolitan ${ }^{4}$ while Kanak journalists from Djiido tend to claim that they are the voice of Kanak people in 'Noumea la Blanche' (see also Chanter 2006) mainly listened, by implication, by a Kanak audience. There is no tangible evidence to date that can verify the validity of 
these statements. However, if such evidence existed and showed that a majority of Kanaks exclusively get their news from indigenous outlets, or that the French settlers solely consume news from metropolitan media, observers like us cannot blame the public — despite the fact that such tendency certainly results 'in the decline of the idea of public interest, of information important to everyone within society' (Moore, 2007, p. 38).

What observers like us should probably be concerned with though, is that - if verified - a selective consumption of the news by the public in New Caledonia, although probably not originated by the media, would now certainly be reinforced by media practitioners themselves as the following statements by local journalists can demonstrate:

Our audience is rather metropolitan, and we write our articles accordingly. (Les Nouvelles Calédoniennes journalist, August 2011)

'La coutume' [custom] is still conveyed through the voice of Radio Djiido; it implies things that you will not find in other radios such as RRB, but at the end our audience is mainly and firstly Kanak. (Radio Djiido journalist, August 2011)

\section{Conclusion}

Fair, transparent and responsible journalism is not only threatened by political or editorial pressures, in New Caledonia, but - to an extent - by journalists themselves whose journalistic practice largely fails to navigate its way between diverse values and principles existing in the complex New Caledonian socio-cultural context.

Observations and primary data collected during research fieldwork in 2011 in New Caledonia suggest that the current divided media landscape of the territory tends to encourage local media to perform their job based on the public interest rather than for the interest of the public.

In an ABC Radio Australia interview (Radio Djiido looks to New Caledonia's future, 25 April 2011), Viviane Arhou, director of Radio Djiido, expressed the will for the radio station to 'play a constructive role' as New Caledonia prepares for the historical referendum that will decide the future of the territory. She admitted though, that 'she found it hard to get non-Kanaks to come on and discuss issues' of independence and autonomy. In this interview, Arhou also admitted to being preoccupied about whether or not Radio Djiido was 'equipped' or had 'a plan' to carry out such a task. 
It is only legitimate to extend these questions to all media in New Caledonia, and ask whether they can all play a constructive role when it comes to giving the public a journalism that will empower them and assist them in the decisions they need to make for their future.

New Caledonia is still effectively a colony of the Republic of France where a self-determination referendum is scheduled between 2014 and 2018. Given this political context, New Caledonian journalists need to reflect on their role and readjust their current practices so they fully fulfil their social function and perform their duties as active representatives of a so-called Fourth Estate.

To achieve this, Pacific media and journalism research, training, and education will play a crucial role. However, there is a need for Pacific media academics to appropriately identify the complex socio-cultural context in which New Caledonian journalists perform their job avoiding the deployment of out-dated frameworks such as the tradition/modernity dichotomy, and contemplating the use of approaches which can also overcome the weaknesses of conventional theories of modernity or post-modernity which tend to ignore 'grassroots' concepts, arguing that they do not suit established ideas about the nature of society and its development.

The work of Polish sociologist, Zygmunt Bauman (2000; 2011), who articulated the notion of liquid modernity could carry - if deployed cautiously_interesting purchases in an attempt to grasp the complexities of New Caledonia's socio-cultural and political context: a liquid modern context.

Liquid modernity is a concept strongly focusing on social change. Bauman (2004) argues, that in liquid modern times, change is the "permanent condition of human life' [...] 'We need to develop ways of behaviour, the ways of contact, which are fit for living in this state of constant change' (p. 5).

Despite being a concept that — like modernity—originated in the West, and although liquid modernity has found little purchase in the scholarly literature encompassing media and journalism to date, Bauman's notion provides enough flexibility to give serious considerations to various social alterations exhibited in some Pacific societies without ignoring local epistemologies and the role they play in shaping some of phenomena observed in this commentary.

In fact, if used to analyse the public and media spheres of New Caledonia, Bauman's concept could prove useful in an attempt to articulate theoretical tools and approaches that could allow to design of journalism training and educational components that can empower local journalists to work proficiently in a delicate political and socio-cultural environment like New Caledonia. 
In other words, if assisted in navigating the tensions posed by what Bauman refers to as liquid modernity, New Caledonian journalists could be in a better position to provide a fair, transparent and responsible journalism to an audience that, during a crucial time of their history, needs all the tools available to make well-informed decisions regarding the future of their country.

This could not be better articulated than through the words of Mark Deuze (2006) who argued:

The future of news will be determined by the extent of its liquidity, its ability to navigate different and sometimes conflicting expectations and our willingness - as journalism scholars and educators - to teach students more than just the tools of a dead (or dying trade) [...] incapable of dealing with the unsettling complexity of the problems and challenges in contemporary liquid life. (Deuze, 2006, p. 4)

\section{Notes}

1. All the interviews used in this commentary have been translated from French to English by the author.

2. The two proposed projects are to be sustained by public subsidies.

3. Nouvelle-Calédonie lére broadcasts local and French programmes.

4. Europeans living and born in New Caledonia for several generations. Note that while many people, especially Anglophones, still use this designation to refer to any 'white' French settlers permanently living in New Caledonia, locally, French settlers are more often referred to as Métros (for Metropolitans) while only the European descendants who have lived in new Caledonia for several generations are the ones referred to as Caldoches.

\section{References}

Bauman, Z. (2000). Liquid modernity. Cambridge \& Oxford, UK: Polity Press \& Blackwell.

Bauman, Z. (2004). Liquid modernity. Paper presented at the ANSE-Conference 'Value dilemmas as a challenge in the practice and concepts of supervision and coaching', Leiden, May 7, 2004.

Bensa, A., and Bourdieu, P. (1985). Quand les Canaques prennent la parole. Actes de la recherche en sciences sociales, 5, 69-85.

Calédonie Ensemble s'oppose à une télévision de propagande. (2012, February 8). Interview transcript. Retrieved on February 17, 2012, from www.caledonieensemble.nc/interview-de-philippe-gomes-concernant-la-tv-de-propagande-rumpuc.html

Chanter, A. (1999). Will there be a morning after? The colonial history of media in New Caledonia. The Journal of Pacific History, 34(1), 91-108. 
Deux nouvelles chaines locales? (2011, October 12). Les Nouvelles Calédoniennes, Retrieved on February 17, 2012, from www.lnc.nc/article/pays/deux-nouvelleschaines-locales

Deuze, M. (2006). Liquid journalism. Political Communication Report, 16(1).

Maclellan, N., and Chesneaux, J. (1998). After oruroa: France in the South Pacific. Ocean Press.

Maclellan, N. (2009). The changing mediascape in New Caledonia broadens the political spectrum. Pacific Journalism Review, 15(2), 205-209.

M'Balla-Ndi, M., Harrison, J. (2012). Real news or reality TV show? What will post-colonial public broadcasting in the Francophone Pacific look like? Media Development. 3\&4/2012, 17-22.

Meadows, M. (2005). Journalism and indigenous public spheres. Pacific Journalism Review, 11(1), 36-42.

Moore, M. (2007). Public interest, media neglect. British Journalism Review, 18(33), 33-40.

Perrottet, A., and Robie, D. (2011). Pacific media freedom 2011: A status report. Pacific Journalism Review, 17(2), 148-186.

Radio Djiido looks at New Caledonia's future (2011, April 25). Radio Australia [Audio podcast]. Retrieved on February 17, 2012, from www.radioaustralia.net. $\mathrm{au} /$ international/radio/program/pacific-beat/radio-djiido-looks-to-new-caledoniasfuture $/ 933378$

Small, J. (2013, April 6). Sale of New Caledonia's daily newspaper stirs press strike, debate. Pacific Scoop. Retrieved on April 12, 2013, from http://pacific.scoop. co.nz/2013/04/sale-of-new-caledonias-daily-newspaper-stirs-free-press-strikedebate/

Marie M'Balla-Ndi is a French journalist and a lecturer in Multimedia Journalism at James Cook University, Townsville, Queensland, Australia. M'Balla-Ndi's research interests include journalism practice in the South Pacific region and her doctoral research examines journalism practice in Vanuatu, Samoa and New Caledonia.

marie.mballandi@jcu.edu.au 